\title{
MENINGKATKAN HASIL BELAJAR MATEMATIKA SISWA \\ DENGAN MENGGUNAKAN MODEL PEMBELAJARAN \\ KOOPERATIF TIPE THINK-PAIR-SHARE (TPS) \\ PADA SISWA KELAS VB SD MUHAMMADIYAH I SORONG
}

\author{
Nika Fetria Trisnawati \\ Jurusan Pendidikan MatematikaFakultas Keguruan dan Ilmu \\ Pendidikan Universitas Muhammadiyah Sorong \\ e-mail: nfetristrisnawati@gmail.com
}

\begin{abstract}
This research aims to describe the Cooperative Learning Model Type ThinkPair-Share (TPS) that can improve students' mathematics learning outcomes. The research was conducted in sorong. The subject of this research was fifth grade class B at SD Muhammadiyah I Sorong in academic year 2010/2011. The students consist of 14 males and 24 females. The research was Classroom Action Research (PTK). The procedure and Implementation at the study site was divided into two cycles. In the first cycle performed four times of implementation by using Cooperative Learning Model Type Think-Pair-Share (TPS). The second cycle took four times with the same model. The observations took with the observation sheet has been prepared, and then reflected by writer and teacher to evaluate the research that has been run on each cycle and to improve the implementation of the next cycle. The technique of data collection was done by using observation and tests. The data were performed with qualitative and quantitative analysis. The results of this study indicate that students' mathematics learning outcomes at $S D$ Muhammadiyah I fifth grade class B increases. At the beginning of test the average was 5,40 and at the end of the first cycle mean score was 5.84. Being at the end of second cycle the average was of 8,09. The action did to stimulate the students' attention by giving preliminary description of matter at the beginning of the meeting, the student group discussions and presentations, providing competition, growing students' curiosity by implementing the Cooperative Learning Model Type Think-Pair-Share (TPS). Giving the relevance of study based on students' experience and providing them the example that is relevant to students. To increase the students self confidence was done by giving them the opportunity to answer questions and write them down in front, giving verbal praise who are successful, providing the opportunity to the group to present the result of discussion, and provide feedback. To increase student satisfaction with verbal praise who are successful, notify the student test results obtained, and giving appropriate rewards and not excessive.
\end{abstract}

Keyword: Hasil belajar, Think-Pair-Share, Matematika 


\section{PENDAHULUAN}

Upaya meningkatan mutu pendidikan saat ini tentunya tidak terlepas dari proses pendidikan yang terkait dengan kegiatan belajar mengajar di kelas. maka guru memegang peranan penting dalam mengarahkan siswa untuk mencapai hasil belajar yang maksimal. Salah satu kemampuan yang diharapkan dikuasai oleh pendidik yaitu bagaimana mengajarkan materi pelajaran dengan baik dan benar, dalam hal ini penguasaan materi dan cara pemilihan model, metode atau teknik pembelajaran yang sesuai sangat mempengaruhi proses dan hasil pembelajaran.

Dalam Kurikulum Tingkat Satuan Pendidikan (KTSP), pembelajaran matematika diharapkan berorientasi pada keterampilan proses, Dengan demikian peran aktif siswa sangat menentukan terhadap keberhasilan pembelajaran. Selama ini proses pembelajaran matematika yang dilakukan masih berpusat pada guru, yaitu guru memberikan materi kepada siswa sedangkan siswa hanya mendengarkan atau mencatat apa yang disampaikan guru. Hal ini membuat proses pembelajaran hanya berlangsung satu arah. Dengan proses pembelajaran seperti ini membuat siswa menjadi pasif, merasa bosan dan tidak tertarik terhadap pembelajaran matematika.. Hal inilah yang mengakibatkan pola belajar siswa cenderung menghafal, serta kemampuan berpikir dan daya analisis siswa kurang berkembang sehingga tujuan pembelajaran tidak tercapai dengan maksimal dan mengakibatkan rendahnya hasil belajar siswa.

memotivasi siswa dalam belajar sehingga hasil belajar siswa dapat meningkat pula.

\section{Rumusan Masalah}

Apakah hasil belajar matematika siswa kelas VB SD Muhammadiyah I Sorong pada materi menggunakan pecahan dalam pemecahan masalah dapat ditingkatkan melalui model pembelajaran kooperatif tipe Think-Pair-Share (TPS) 


\section{METODE PENELITIAN}

\section{Jenis dan Desain Penelitian}

Penelitian ini merupakan Penelitian Tindakan Kelas (Classroom Action Research) yang dilakukan peneliti. Peran peneliti ialah sebagai perancang, pelaksana dan pengamat. Penelitian ini dilaksanakan untuk mendapatkan gambaran nyata tentang kualitas pembelajaran matematika menggunakan model pembelajaran kooperatif tipe Think- Pair-Share (TPS).

\section{Subyek Penelitian}

Pada penelitian ini yang menjadi subyek penelitian yaitu siswa kelas VB SD Muhammadiyah I Remu Utara Sorong Tahun ajaran 2010-2011 yang berjumlah 38 siswa terdiri dari 14 siswa laki-laki dan 24 siswa perempuan dengan lokasi sekolah jalan puyuh nomor 4 Remu utara, Sorong. Penelitian ini dilaksanakan pada bulan April s/d Mei 2011 dengan menyesuaikan jadwal pelajaran matematika di kelas tersebut. Instrumen Penelitian penelitian ini yaitu: a) lembar Observasi yang digunakan Sebagai panduan dalam mengamati aktivitas siswa selama proses pembelajaran berlangsung; b) lembar tes digunakan untuk mengetahui hasil belajar matematika siswa setelah dilakukan pembelajaran dengan model pembelajaran kooperatif tipe Think-Pair-Share (TPS).

\section{HASIL DAN PEMBAHASAN}

Analisis skor hasil tes dari hasil belajar matematika disajikan dalam Tabel 1 berikut:

\begin{tabular}{llcc}
\multicolumn{3}{l}{ Tabel 1. Statistik Nilai Tes Hasil Siklus I } \\
\multicolumn{4}{c}{ dan Siklus II } \\
\hline N & Nilai & Nilai \\
o & Statistik & Statistik & Statistik \\
& & slklus__ & slklus._L \\
\hline 1 & Subjek & 38 & 38 \\
2 & Nilai Ideal & 10 & 10 \\
3 & Nilai Tertinggi & 10 & 10 \\
4 & Nilai Terendah & 3.2 & 5 \\
5 & Rentang Nilai & 6.8 & 5 \\
6 & Rata-Rata Nilai & 5.84 & 8.09 \\
7 & Standar Deviasi & 1.47 & 1.42 \\
8 & Modus & $5.6($ a) & 9.6 \\
\hline
\end{tabular}


Jika nilai siswa dikelompokkan ke dalam lima kategori dari departemen pendidikan, maka diperoleh distribusi frekuensi nilai dari siklus I dan Siklus II seperti pada tabel di bawah ini:

\begin{tabular}{ccccccc}
\multicolumn{8}{c}{ Tabel 2.Distribusi Frekuensi dan } \\
\multicolumn{6}{c}{ Persentase SkorTes } \\
\hline \multirow{2}{*}{ N } & & vir & Siklus I & \multicolumn{3}{c}{ Siklus II } \\
o & Nilai & teg & Fr & Perse & Fr & Perse \\
& & erk & ntase & ek & ntase \\
& & ori & ue & $(\%)$ & ue & $(\%)$ \\
& & & nsi & & nsi & \\
\hline 1 & $0-5.4$ & SR & 13 & 34.21 & 1 & 2.63 \\
2 & $5.5-6.4$ & R & 14 & 36.84 & 7 & 18.42 \\
3 & $6.5-7.9$ & S & 8 & 21.05 & 3 & 7.89 \\
4 & $8-8.9$ & T & 0 & 0.00 & 14 & 36.84 \\
5 & $9-10$ & ST & 3 & 7.89 & 13 & 34.21 \\
\hline & Jumlah & & 38 & 100 & 38 & 100
\end{tabular}

Keterangan:

SR : Sangat Rendah

R : Rendah

S : : Sedang

$\mathrm{T} \quad$ : Tinggi

ST : Sangat Tinggi

Jika hasil belajar siswa dianalisis, maka persentase ketuntasan belajar siswa dapat dilihat pada tabel 3 berikut ini :

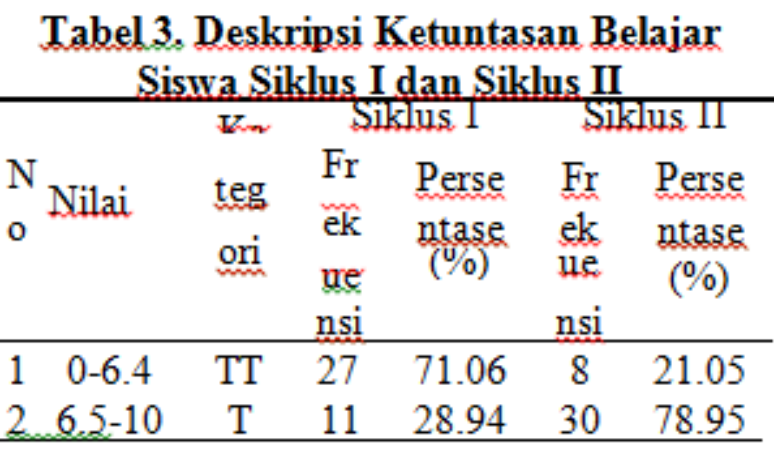

Keterangan: TT : Tidak Tuntas

$$
\mathrm{T}: \text { Tuntas }
$$


Partisipasi siswa dalam pembelajaran dapat dilihat dari table berikut:

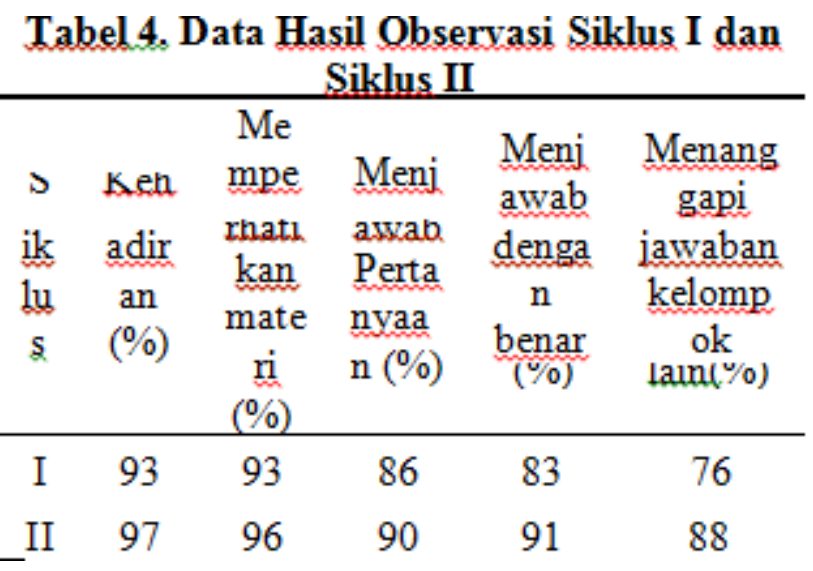

\section{SIMPULAN}

Terjadi peningkatan pada jumlah siswa yang tuntas belajar, yaitu pada Siklus I persentase siswa yang tuntas belajar sebesar $28,94 \%$ dan yang tidak tuntas belajar sebesar 71,06\%. Sedangkan pada Siklus II, persentase siswa yang tuntas belajar sebesar $78,95 \%$ dan yang tidak tuntas belajar sebesar 21,05\%.

Model pembelajaran kooperatif tipe TPS dapat meningkatan hasil belajar matematika siswa kelas VB SD Muhammadiyah I Sorong. Peningkatan tersebut dapat dilihat dari skor rata-rata Siklus I sebesar 5,84 dengan standar deviasi 1,47 menjadi sebesar 8,09 dengan standar deviasi 1,42 pada Siklus II.

Melalui model pembelajaran kooperatif tipe TPS dapat meningkatkan keaktifan siswa di dalam kelas dan menumbuhkan keberanian siswa mengemukakan pendapat serta rasa takut siswa terhadap pelajaran matematika.

\section{DAFTAR PUSTAKA}

Arikunto, Suharsimi. 2006. Prosedur Penelitian Suatu Pendekatan Praktik. Jakarta: Rineka Cipta. . 2010. Dasar-Dasar Evaluasi Pendidikan. Jakarta: Bumi Aksara.

Budiharso, Teguh. 2009. Panduan Lengkap Penulisan Karya Ilmiah, Skripsi, Thesis dan Disertasi. Yogyakarta: Venus. 
Dimyati, Mudjiono.1994. Belajar dan Pembelajaran. Jakarta : Departemen Pendidikan dan Kebudayaan.

FKIP UNAMIN Sorong. Panduan Penulisan Skripsi. 2010. Sorong

Hadis, A. 2006. Psikologi dalam Pendidikan. Bandung: Alfabeta.

Hamalik, Oemar. 2005. Proses Belajar Mengajar. Jakarta: Bumi Aksara.

Hertanto, Ardian Tri. 2008. Upaya Meningkatkan Motivasi dan Prestasi Belajar Siswa Kelas X SMA Negeri 1 Sleman dengan "Mathematics Motivated Learning” Model ARCS. Skripsi, Yogyakarta,FMIPA UNY.

Anonim.http.www.ditnaga- dikti.org/think,pair,share. Didownload pada tanggal 24 Februari 2011

.http.www.readingquest.org/think,pair,s hare. Didownload pada tanggal 24 februari 2011

.http://www.ditnaga- dikti.org/ditnaga/files/PIP/kooperatif.pdf. didownload pada tanggal 14 Februari 2011

Lyman.1981. Think-Pair-Share. Diakses pada 7Maret 2011 dari

http://www.readingquest.org/strat/tps.h tml

Muliati. 2008. Penulisan Karya Ilmiah. Diktat disajikan dalam perkuliahan

Penulisan Karya Ilmiah Mahasiswa Jurusan Pendidikan Matematika FKIP UNAMIN Sorong.

Mu'addab, Hafis. 2010. Pengertian Belajar Matematika. http://hafismuaddab.wordpress.com/20 $\quad$ 10/01/13/pengertian-belajarmatematika/, Diakses pada tanggal 13 Februari 2011

Nurmiati, 2009. Pembelajaran Matematika dengan Model Pembelajaran Kooperatif Tipe Teams Game Tournaments untuk Meningkatkan Hasil Belajar Siswa. Skripsi, Yogyakarta, FMIPA UNY

Rumini, Sri dkk. 1993. Psikologi Pendidikan.

Yogyakarta: Unit Percetakan dan Penerbitan (UPP) Universitas Negeri Yogyakarta

Sampurno, Agus (2008). Think, Pair and Share (Berfikir, Berpasangan, dan

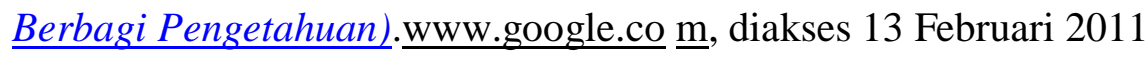

Simanjuntak Lisnawati, dkk, 1993. Metode Mengajar Matematika I. Jakarta: 


\section{Rineka Cipta.}

Slameto. 2010. Belajar dan Faktor-Faktor yang Mempengaruhinya. Jakarta: Rineka Cipta.

Soenarjo, RJ. 2008. Matematika 5. Jakarta: Departemen Pendidikan Nasional.

Sudjana, Nana, Ahmad Rivai. 2007. Teknologi Pengajaran. Bandung: Sinar Baru Algesindo

Sudjana, Nana.2001. Penilaian Hasil Proses Belajar Mengajar. Bandung: Remaja Rosdakarya

Sugiyono. 2010. Metode Penelitian Kuantitatif kualitatif dan $R \& D$. Bandung: Alfabeta.

Suherman, Erman dkk. 2003. Strategi Pembelajaran Matematika

Kontemporer. Bandung:JICA- Universitas Pendidikan Indonesia

Sulardi, 2006. Pandai Berhitung Matematika5. Jakarta: Penerbit Erlangga.

Syah, Muhibbin. 2008. Psikologi Pendidikan dengan Pendekatan Baru. Bandung: Remaja Rosdakarya.

Tim Bina Karya Guru. 2001. Terampil Berhitung Matematika untuk Kelas V. Jakarta: Penerbit Erlangga.

Tim Subdit Pembelajaran. 2010. Model Bahan Ajar matematika untuk Sekolah

Dasar. Jakarta: Direktorat Pembinaan Taman Kanak-Kanak dan Sekolah Dasar, Direktorat Jenderal Manajemen Pendidikan Dasar dan Menengah, Kementrian Pendidikan Nasional. 